\title{
Cytotoxic effects of rubratoxin $B$ on cultured cells
}

\author{
Hitoshi NAGASHIMA*
}

(Received Aug. 14, 1995 ; Accepted Jan. 8, 1996)

長嶋 等*：培養細胞に対するルブラトキシン B の細胞毒性

\begin{abstract}
Summary
The cytotoxicity of rubratoxin B was studied in human hepatoma cell HepG2, human uterine tumor cell HeLa and mouse ascites tumor cell Ehrlich. Exposure to rubratoxin B resulted in the cultured cells to be shrunk, and their volumes reduced. The inhibitory dose $50 \%$ $\left(\mathrm{ID}_{50}\right.$ ) of the water soluble tetrazolium-1 assay (Wst-1 ; measurement of the activity of mitochondrial enzyme) were 2- to 3.6 -fold of those of bromo-deoxyuridine incorporation (BrdU ; measurement of the activity of replication). Rubratoxin B did not affect the cell cycle, but brought about a dose-dependent increase of degraded chromosomal DNA. The reduction of cell volume and the degradation of chromosomal DNA may indicate that the toxicity of rubratoxin $B$ is the consequence of apoptosis.
\end{abstract}

Key words : Rubratoxin B，ルブラトキシン B ; Cytotoxicity，細胞毒性；Apoptosis，アポトー シス

Rubratoxin B (Fig. 1) is a toxic metabolite produced by Penicillium rubrum and Penicillium purpurogenum $^{1)}$. Rubratoxin B is a potent hepatotoxic ${ }^{2)}$, mutagenic ${ }^{3)}$ and teratogenic ${ }^{4,5)}$ agent. Histological and biochemical changes such as hepatic degeneration ${ }^{6}$, inhibition of adenosine triphosphatase activities of the brain, kidney and liver ${ }^{7)}$, decrease in levels of hepatic ATP and cyclic $\mathrm{AMP}^{8)}$, inhibition of hepatic cytochrome P-450-dependent monooxygenase ${ }^{\text {9) }}$ and reduction of hepatic and renal nonprotein sulfhydryl content ${ }^{10)}$ by rubratoxin $\mathrm{B}$ have been reported. However, the mechanism of its toxicity remains unclear. Moreover, the toxicity of rubratoxin $\mathrm{B}$ on cultured cells were reported in only a few papers ${ }^{11,12}$. To elucidate the mechanism of toxicity, the cytological effects such as morphological changes, viability and cell cycle of ru-

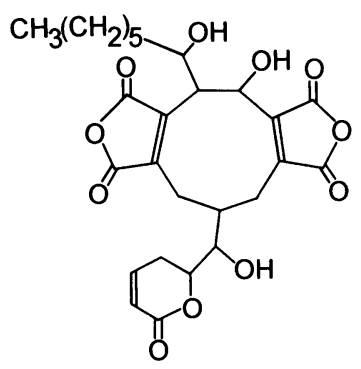

Fig. 1 The structure of rubratoxin B.

* National Food Research Institute, Ministry of Agriculture, Forestry and Fisheries (2-1-2, Kannondai Tsukuba, Ibaraki, 305 Japan)

農林水産省食品総合研究所（テ305 つくば市観音台 2-1-2） 
bratoxin B on cultured cells were investigated.

\section{Materials and Methods}

Chemicals and cells Rubratoxin B was purchased from Makor Chemicals (Israel). Cultured human hepatoma cell HepG2, human uterine tumor cell HeLa and mouse ascites tumor cell Ehrlich were purchased from RIKEN Cell Bank (Saitama). Cells were cultured in Dulbecco's Modified Eagles medium containing 10\% fetal calf serum.

Morphological study Two times $10^{5}$ cells in $100 \mu \mathrm{l}$ of medium with 0,20 and $40 \mu \mathrm{g} / \mathrm{ml}$ of rubratoxin $\mathrm{B}$ were cultured in each well of a 96 -well microtiter plate for $24 \mathrm{hr}$, followed by microscopic examination.

Cytotoxicity of mbratoxin B Cytotoxicity of rubratoxin B was determined by measuring the mitochondrial succinic dehydrogenase activity using the water soluble tetrazolium-1 (WST-1) assay $^{13)}$, and by the rate of cell proliferation as measured by bromo-deoxyuridine (BrdU) incorporation during DNA synthesis. Approximately $1 \times 10^{3}$ to $2 \times 10^{4}$ cells in $100 \mu \mathrm{l}$ of medium with various concentrations of rubratoxin $B$ were placed in each well of a 96 -well microtiter plate. Cytotoxicity was determined after culturing for $24 \mathrm{hr}$. The WST-1 assay ${ }^{13)}$ was performed using Cell Counting Kit (Dojindo Laboratories, Kumamoto). Incorporation of BrdU was measured using Cell Proliferation ELISA, BrdU (Boehringer-Mannheim, Germany).

Analysis of cell cycle Five times $10^{5}$ cells in $2 \mathrm{ml}$ of medium with $0,10,20$ and $40 \mu \mathrm{g} / \mathrm{ml}$ of rubratoxin $\mathrm{B}$ were placed in each well of a 6 -well plate. Cell cycles were analyzed after culturing for $24 \mathrm{hr}$ using Cycle TEST PLUS DNA Reagent kit (Becton Dickinson, USA) and CellFIT software on a FACSort flow cytometer (Becton Dickinson, USA).

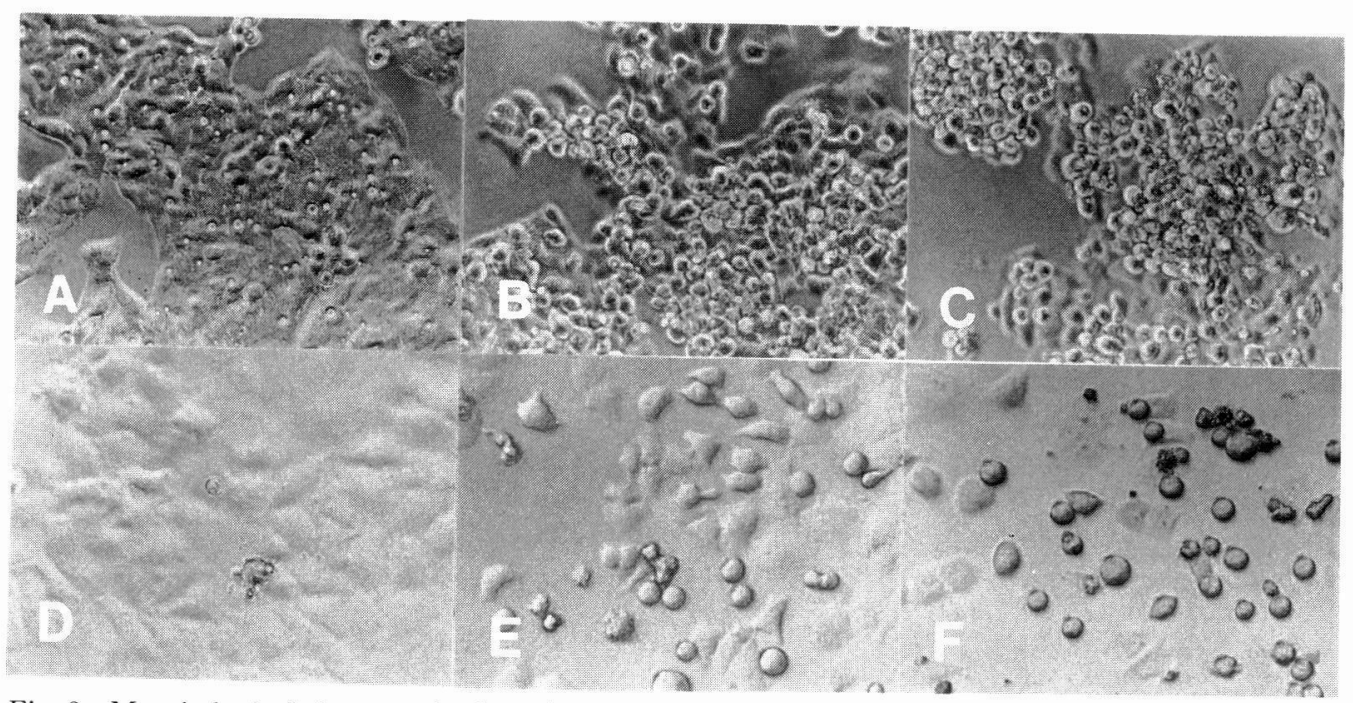

Fig. 2 Morphological changes of cultured cells by rubratoxin B. (A-C), HepG2 cells; (D-F), HeLa cells. (A, D) control; (B, E), treated with $20 \mu \mathrm{g} / \mathrm{ml}$; (C, F), treated with $40 \mu \mathrm{g} / \mathrm{ml}$ of rubratoxin B for $24 \mathrm{hr}$ (Magnification $\times 100$ ). 
Table $1 \mathrm{ID}_{50} \mathrm{~s}$ of rubratoxin $\mathrm{B}$

\begin{tabular}{lccc}
\hline \hline & HepG2 & HeLa & Ehrlich \\
\hline WST-1 assay & $64 \mu \mathrm{g} / \mathrm{ml}$ & $65 \mu \mathrm{g} / \mathrm{ml}$ & $36 \mu \mathrm{g} / \mathrm{ml}$ \\
BrdU incorporation & $20 \mu \mathrm{g} / \mathrm{ml}$ & $18 \mu \mathrm{g} / \mathrm{ml}$ & $18 \mu \mathrm{g} / \mathrm{ml}$ \\
\hline WST-1/BrdU ID s0 $_{\text {ratio }}$ & 3.2 & 3.6 & 2.0 \\
\hline
\end{tabular}

(A)

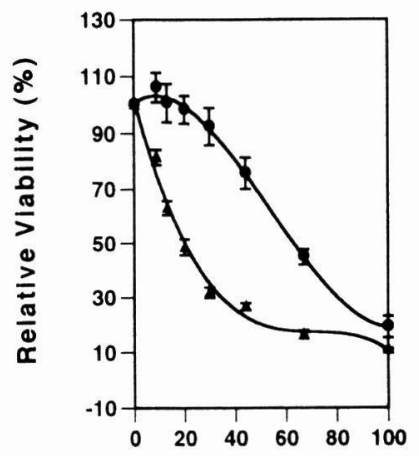

(B)

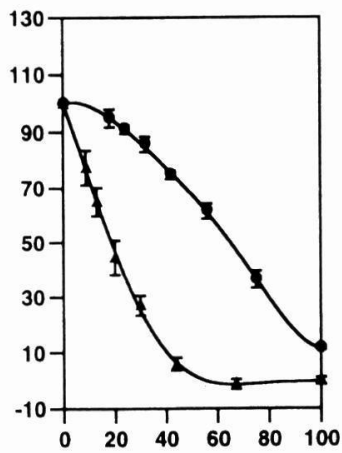

(C)

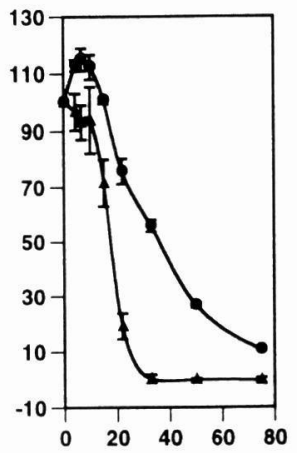

Concentration of Rubratoxin B $(\mu \mathrm{g} / \mathrm{ml})$

Fig. 3 Effects of rubratoxin B on viability of cultured cells. (A), HepG2 cells; (B), HeLa cells; (C), Ehrlich cells. The viability of the cells was determined by WST-1 assay (closed circle) and BrdU incorporation (closed triangle) after $24 \mathrm{hr}$-culture. Vertical lines indicate the relative viability. Each symbol is the mean of for individual samples. Error bars indicate standard deviations.

\section{Results and Discussion}

As shown in Fig. 2, HepG2 and HeLa cells were shrunk, and their volumes were reduced after treatment with rubratoxin B. In HepG2 cells, the tight cell adhesion (Fig. 2A) was loosened and gaps between cells were observed (Fig. 2B, 2C). These observations suggest that rubratoxin $\mathrm{B}$ may affect the expression of cytoskeltons and intercellular structures.

The inhibitory dose $50 \%\left(\mathrm{ID}_{50}\right) \mathrm{s}$ of rubratoxin $\mathrm{B}$ were determined from the dose-dependent curve of viability (Fig. 3). ID $_{50} \mathrm{~S}$ as measured by the WST-1 assay and by BrdU incorporation were 64 and $20 \mu \mathrm{g} / \mathrm{ml}$ in HepG2 cells, 65 and $18 \mu \mathrm{g} / \mathrm{ml}$ in HeLa cells and 36 and $18 \mu \mathrm{g} / \mathrm{ml}$ in Ehrlich cells, respectively (Table 1). As shown in Fig. 3, the differences in viability determined by two methods were apparent, and $\mathrm{ID}_{50}$ s from the WST-1 assay were 2-(Ehrlich), 3.2-(HepG2) and 3.6-(HeLa) fold greater than $\mathrm{ID}_{50}$ s measured by BrdU incorporation (Table 1). The reasons for the observed differences between the two methods are not clear, although it may be due to a direct damaging effect on chromosomes by rubratoxin $\mathrm{B}$, as suggested by Umeda et al. ${ }^{12}$. Umeda $e$ a $a{ }^{12)}$ reported that rubratoxin B inhibited DNA synthesis in HeLa cells, and indicated that its $\mathrm{ID}_{50}$ was approximately $200 \mu \mathrm{g} / \mathrm{ml}$. Although the $\mathrm{ID}_{50}$ in HeLa cells observed in this study was much less, the cells were cultured for $24 \mathrm{hr}$ as opposed to the one hr exposure period 
A

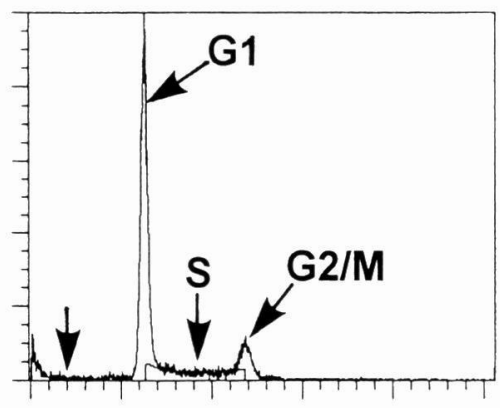

\section{C}

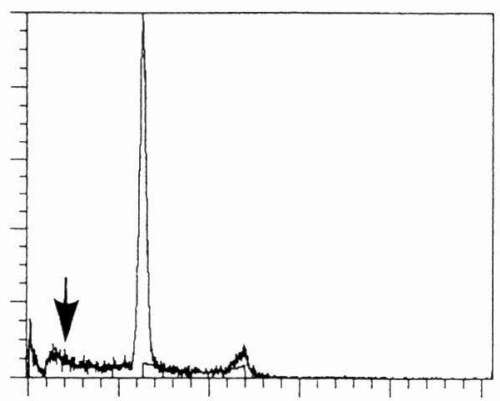

B

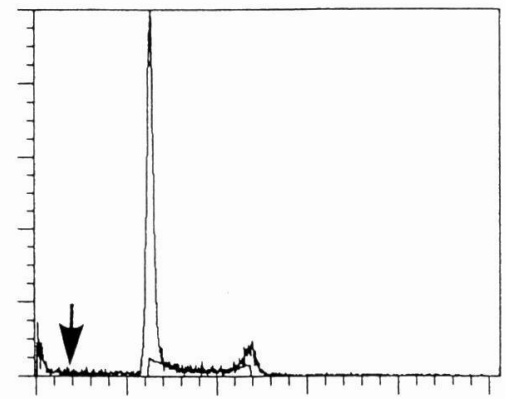

D

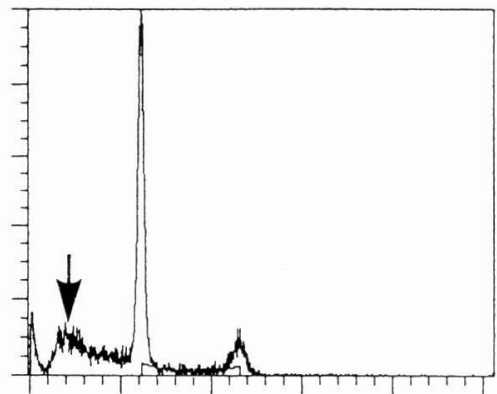

Fig. 4 Flow cytometric analysis of HeLa cells. (A), treated with $0 \mu \mathrm{g} / \mathrm{ml}$; (B), treated with $10 \mu \mathrm{g} / \mathrm{ml}$; (C), treated with $20 \mu \mathrm{g} / \mathrm{ml}$; (D), treated with $40 \mu \mathrm{g} / \mathrm{ml}$ of rubratoxin B for $24 \mathrm{hr}$. G1, S and G2/ $\mathrm{M}$ represent the peaks of G1, S and G2/M phase, respectively. Arrows represent the peaks of degraded DNA. The vertical and the horizontal lines indicate the cell numbers and the fluorescence intensities of propidium iodide, respectively.

by Umeda et al. ${ }^{12)}$.

Rubratoxin B did not affect the rate of the specific phase of HeLa cells (Fig. 4). A distinct change observed in the rubratoxin B-exposed HeLa cells was a dose-dependent increase of degraded chromosomal DNA(Fig. 4). The same effect was also observed in HepG2 and Ehrlich cells (data not shown). Although Umeda et al. reported that rubratoxin B elongated the M phase of HeLa cells ${ }^{12)}$, dose-dependent changes in cell cycle was not observed in this study (Fig. 4). DNA degradation has been reported to be a consequence of apoptosis ${ }^{14)}$. In addition to the reduction of cell volumes (Fig. 2) and degraded chromosomal DNA (Fig. 4) observed in this study, Umeda et al. ${ }^{12)}$, Lockard et $a l .{ }^{15)}$ and Engelhardt et $a l .{ }^{16)}$ also observed characteristics of apoptosis by rubratoxin $\mathrm{B}$ namely, the appearance of polynuclear HeLa cells ${ }^{12)}$, morphological changes in liver with random multifocal areas $^{15)}$, and the loss of renal microvilli16), respectively. Therefore, the observations in this study may indicate that the toxicity of rubratoxin $\mathrm{B}$ to be the consequence of apoptosis.

Acknowledgements I wish to thank Mr. Tetsuhisa Goto for discussion and encouragement and Dr. Mark Y. Fukayama for his editorial efforts on this manuscript. 


\section{References}

1) Wilson, B. J., Harbison, R. D. : J. Amer. Vet. Med. Assoc., 163, 1274 (1973).

2) Burnside, J. E., Sippel, W. L., Forgas, J., Caroll, W. J., Atwood, M. B., Doll, E. R. : Amer. J. Vet. Res., 18, 817 (1957).

3) Evans, M. A., Harbison, R. D. : Toxicol. Appl. Pharmacol., 39, 13 (1977).

4) Hood, R. D., Innes, J. E., Hayes, A. W. : Bull. Environ. Contam. Toxicol., 10, 200 (1973).

5) Koshakji, R. P., Wilson, B. J., Harbison, R. D. : Res. Commun. Chem. Pathol. Pharmacol., 5, 584 (1973).

6) Wagon, G. N., Edwards, G. S., Newberne, P. M. : Toxicol. Appl. Pharmacol., 19, 712 (1971).

7) Desaiah, D., Hayes, A. W., Ho, I. K.: Toxicol. Appl. Pharmacol., 39, 71 (1977).

8) Hayes, A. W., Hoskins, B., Pfaffman, M. A., Watson, S. A. : Toxicol. Lett., 1, 241 (1978).

9) Siraj, M. Y., Hayes, A. W.: Toxicol. Appl. Pharmacol., 48, 351 (1979).

10) Engelhardt, J. A., Carlton, W. W., Carlson, G. P., Hayes, A. W. : Toxicol. Appl. Pharmacol., 96, 85 (1988).

11) Robb, J., Norval, M., Neil, W. A. : Lett. Appl. Microbiol., 10, 161 (1990).

12) Umeda, M., Saito, A., Saito, M. : Jpn. J. Exp. Med., 40, 409 (1970).

13) Ishiyama, M., Shiga, M., Sasamoto, K., Mizoguchi, M., He, P.: Chem. Pharm. Bull., 41, 1118 (1993).

14) Kerr, J. F. R., Wyllie, A. H., Currie, A. R. : Br. J. Cancer, 26, 239 (1972).

15) Lockard, V. G., Watson, S. A., Siraji, M. Y., Hayes, A. W., O’Neal, R. M. : Exp. Mol. Pathol., 34, 94, (1981).

16) Engelhardt, J. A., Carlton, W. W., Hinsman, E. J., Hayes, A. W. : Exp. Mol. Pathol., 50, 193, (1989). 